\title{
Hubungan Pelaksanaan Pengelolaan Kelas Terhadap Kegiatan Belajar Mengajar Pada Mata Pelajaran Pendidikan Kewarganegaraan Di Madrasah Ibtidaiyah Negeri Kecamatan Tembilahan
}

\author{
Nia Pratiwi ${ }^{1}$, Mardiah ${ }^{2}$ \\ ${ }^{1}$ Pendidikan Guru Madrasah Ibtidaiyah, STAI Auliaurrasyidin, Tembilahan Riau, Indonesia \\ ${ }^{2}$ Pendidikan Guru Madrasah Ibtidaiyah, STAI Auliaurrasyidin, Tembilahan Riau, Indonesia \\ *Corresponding author: niapratiwi@gmail.com \\ *Corresponding author: mardiah.mawardi@gmail.com
}

\begin{abstract}
Abstrak
Masalah pokok yang dihadapi guru, baik yang pemula maupun yang sudah berpengalaman adalah masalah pengelolaan kelas, yang merupakan aspek yang sering didiskusikan oleh para pengajar. Pengelolaan kelas merupakan masalah tingkah laku yang kompleks, dan guru menggunakannya untuk menciptakan dan mempertahankan kondisi kelas sedemikian rupa, sehingga anak didik dapat mencapai tujuan pengajaran secara efisien dan memungkinkan mereka dapat belajar. Tujuan penelitian adalah untuk mengetahui hubungan pelaksanaan pengelolaan kelas terhadap kegiatan belajar mengajar pada mata pelajaran Pendidikan Kewarganegaraan di Madrasah Ibtidaiyah Negeri Kecamatan Tembilahan Penelitian ini dilakukan di Madrasah Ibtidaiyah Negeri Kecamatan Tembilahan. Penelitian ini dilakukan selama 3 bulan setelah surat riset dikeluarkan. Subjek dalam penelitian ini adalah guru Pendidikan Kewarganegaraan. Objek dalam penelitian ini adalah hubungan pelaksanaan pengelolaan kelas terhadap kegiatan belajar mengajar pada mata pelajaran Pendidikan Kewarganegaraan di Madrasah Ibtidaiyah Negeri Kecamatan Tembilahan. Hasil dari penelitian menunjukkan bahwa dari observasi yang penulis lakukan, maka penulis menemukan ada hubungan pelaksanaan pengelolaan kelas terhadap kegiatan belajar mengajar pada mata pelajaran Pendidikan Kewarganegaraan di Madrasah Ibtidaiyah Negeri Kecamatan Tembilahan ada hubungannya ini terlihat dari hasil akhir yang penulis temukan bahwa thitung lebih besar dari $t_{\text {tabel }}$ atau 3,41 >1,812 maka Ho ditolak, artinya ada hubungan.
\end{abstract}

Kata Kunci: Pengelolaan Kelas, Kegiatan Belajar, Mengajar

\section{PENDAHULUAN}

Proses pembelajaran merupakan suatu proses yang mengandung serangkaian perbuatan guru dan siswa atas dasar hubungan timbal balik yang berlangsung dalam situasi edukatif untuk mencapai tujuan tertentu. Interaksi atau hubungan timbal balik antara guru dan siswa itu merupakan syarat utama bagi berlangsungnya proses belajar mengajar. 
Dalam proses belajar mengajar tersirat adanya suatu kegiatan yang tidak terpisahkan antar siswa yang belajar dan guru yang mengajar. Antara kedua kegiatan ini terjalin interaksi yang saling menunjang. Belajar adalah suatu proses usaha yang dilakukan seeorang untuk memperoleh suatu perubahan tingkahlaku yang baru secara keseluruhan, sebagai hasil pengalamannya sendiri dalam interaksi dengan lingkungan. ${ }^{1}$

Guru memiliki peran yang sangat penting dalam menentukan kuantitas dan kualitas pengajaran yang dilaksanakannya. Oleh karena itu, guru harus memikirkan dan membuat perencanaan dalam meningkatkan kesempatan belajar bagi siswanya dan memperbaiki kualitas mengajarnya. Hal ini menuntut perubahan-perubahan dalam pengorganisasian kelas, penggunaan metode mengajar, strategi belajar mengajar, maupun sikap dan karakteristik guru dalam mengelola proses belajar mengajar. Guru dituntut untuk mampu mengelola proses belajar mengajar yang memberikan rangsangan kepada siswa sehingga siswa mau belajar.

Masalah pokok yang dihadapi guru, baik yang pemula maupun yang sudah berpengalaman adalah masalah pengelolaan kelas, yang merupakan aspek yang sering didiskusikan oleh para pengajar. Pengelolaan kelas merupakan masalah tingkah laku yang kompleks, dan guru menggunakannya untuk menciptakan dan mempertahankan kondisi kelas sedemikian rupa, sehingga anak didik dapat mencapai tujuan pengajaran secara efisien dan memungkinkan mereka dapat belajar. ${ }^{2}$

Pengelolaan kelas adalah keterampilan guru untuk menciptakan dan memelihara kondisi belajar yang optimal bagi terjadinya proses belajar mengajar. ${ }^{3}$ Tujuan umum pengelolaan kelas ialah menyediakan dan menggunakan fasilitas kelas untuk bermacammacam kegiatan belajar dan mengajar agar mencapai hasil yang baik. Sedangkan tujuan khusus adalah mengembangkan kemampuan siswa dalam menggunakan alat-alat belajar, menyediakan kondisi-kondisi yang memungkinkan siswa bekerja dan belajar, serta membantu siswa untuk memperolah hasil yang diharapkan. ${ }^{4}$

Peranan guru sebagai pengelola kelas, berusaha menciptakan kondisi belajar mengajar yang efektif sehingga memungkinkan proses belajar mengajar berjalan lancar dan efektif. Guru juga berperan mengembangkan bahan pelajaran dengan baik dan meningkatkan kemampuan siswa untuk menyimak pelajaran yang menguasai tujuantujuan pendidikan yang harus mereka capai.

Peran guru sebagai pengelola kelas (learning manager), hendaknya mampu mengelola kelas sebagai lingkungan belajar serta merupakan aspek dari lingkungan sekolah yang perlu diorgani-sasi. Lingkungan ini diatur dan diawasi agar kegiatankegiatan belajar terarah kepada tujuan-tujuan pendidikan. Pengawasan terhadap lingkungan belajar itu turut menentukan sejauhmana lingkungan tersebut menjadi

\footnotetext{
${ }^{1}$ Slameto. Belajar dan Faktor-Faktor yang Mempengaruhinya, (Jakarta: Rineka Cipta, 2003), hlm. 2.

${ }^{2}$ Syaiful Bahri Djamarah dan Aswan Zain, Strategi Belajar Mengajar (Jakarta: PT. Reneka Cipta, 2006), hlm. 194.

${ }^{3}$ Ibid., hlm. 194.

${ }^{4}$ Moh. Uzer Usman, Menjadi Guru Profesional, (Bandung: PT. Remaja Rosda Karya, 2005), hlm. 10.
} 
lingkungan belajar yang baik. Lingkungan yang baik ialah yang bersifat menantang dan merangsang siswa untuk belajar, memberikan rasa aman dan kepuasan dalam mencapai tujuan.

Kaitan dengan proses belajar mengajar hendaknya guru dapat mengarahkan dan membimbing siswa untuk aktif dalam kegiatan belajar mengajar sehingga tercipta suatu interaksi yang baik antara guru dengan siswa maupun siswa dengan siswa.

Sangat penting artinya bagi seorang guru untuk memberikan kondisi yang kondusif bagi siswa di dalam kelas. Kemampuan guru memberikan kondisi kondusif tersebut biasa disebut dengan keterampilan mengelola kelas. Keterampilan mengelola kelas pada hakikatnya adalah keterampilan guru untuk menciptakan dan memelihara kondisi belajar yang optimal dan mengembalikannya bila terjadi gangguan dalam proses belajar mengajar. ${ }^{5}$

Proses pembelajaran, pengelolaan kelas memiliki peranan penting dalam meningkatkan sikap belajar siswa, hal ini sejalan dengan pendapat Syaiful Bahri Djamarah, merupakan kemampuan guru atau wali kelas dalam memberdayagunakan potensi kelas berupa pemberian kesempatan yang seluas-luasnya pada setiap personal untuk melakukan kegiatan-kegiatan kelas yang berkaitan dengan kurikulum dan perkembangan siswa. ${ }^{6}$

\section{METODE PENELITIAN}

Penelitian yang dilakukan ini memiliki dua variabel yaitu variabel bebas $(\mathrm{X})$ dan variabel terikat (Y). Yang digunakan sebagai variabel bebas adalah pelaksanaan pengelolaan kelas. Sedangkan varibel terikatnya adalah kegiatan belajar mengajar.

Untuk mengetahui hubungan pelaksanaan pengelolaan kelas terhadap kegiatan belajar mengajar pada mata pelajaran Pendidikan Kewarganegaraan di Madrasah Ibtidaiyah Negeri Kecamatan Tembilahan, ada atau tidaknya hubungan keduanya maka teknik yang penulis pakai untuk menganalisa data adalah teknik korelasi Product moment.

Dalam penelitian ini menggunakan rumus dengan korelasi product moment berikut:

$$
r_{\mathrm{xy}}=\frac{\mathrm{n} \cdot\left(\sum \mathrm{XY}\right)-\left(\sum \mathrm{X}\right) \cdot\left(\sum \mathrm{Y}\right)}{\sqrt{\left\{\mathrm{n} \cdot \Sigma \mathrm{X}^{2}-\left(\sum \mathrm{X}\right)^{2}\right\} \cdot\left\{\mathrm{n} \cdot \sum \mathrm{Y}^{2}-\left(\sum \mathrm{Y}\right)^{2}\right\}}}
$$

$\begin{array}{llll}\text { Ket : } & \mathrm{r}_{\mathrm{xy} \text { hitung }} & : & \text { koefisien korelasi } \\ & \sum \mathrm{X} & : & \text { Jumlah skor item } \\ & \sum \mathrm{Y} & : & \text { Jumlah skor total (seluruh item) } \\ \mathrm{n} & : & \text { Jumlah responden. }\end{array}$

\section{HASIL DAN PEMBAHASAN}

${ }^{5}$ Moh. Uzer Usman, op.cit., hlm. 97.

${ }^{6}$ Syaiful Bahri Djamarah, Strategi Belajar Mengajar, (Jakarta: Rineka Cipta, 2006), hlm. 177. 
Untuk mengetahui jawaban permasalahan dalam penelitan ini, maka data hasil observasi akan dimasukkan ke dalam tabel rekapitulasi sebagai berikut:

Tabel 1.

Rekapitulasi Hasil Observasi Tentang Tentang Pelaksanaan Pengelolaan Kelas Oleh Guru Pendidikan Kewarganegaraan Di Madrasah Ibtidaiyah Negeri Kecamatan Tembilahan (Variabel X)

\begin{tabular}{|c|c|c|c|c|c|c|c|}
\hline \multirow{2}{*}{ No } & \multirow{2}{*}{ TABEL } & \multicolumn{4}{|c|}{ HASIL OBSERVASI } & \multicolumn{2}{|c|}{ Jumlah } \\
\hline & & Ya & $\mathbf{P}(\%)$ & Tidak & $\mathbf{P}(\%)$ & $\mathbf{F}$ & $\mathbf{P}(\%)$ \\
\hline 1 & IV.4 & 10 & $76,9 \%$ & 3 & $23,1 \%$ & 13 & $100 \%$ \\
\hline 2 & IV.5 & 10 & $76,9 \%$ & 3 & $23,1 \%$ & 13 & $100 \%$ \\
\hline 3 & IV.6 & 10 & $76,9 \%$ & 3 & $23,1 \%$ & 13 & $100 \%$ \\
\hline 4 & IV.7 & 10 & $76,9 \%$ & 3 & $23,1 \%$ & 13 & $100 \%$ \\
\hline 5 & IV.8 & 10 & $76,9 \%$ & 3 & $23,1 \%$ & 13 & $100 \%$ \\
\hline 6 & IV.9 & 9 & $69,2 \%$ & 4 & $30,8 \%$ & 13 & $100 \%$ \\
\hline & ILAH & 59 & $75,6 \%$ & 19 & $24,4 \%$ & 78 & $100 \%$ \\
\hline
\end{tabular}

Untuk mengetahui jawaban permasalahan dalam penelitan ini, maka data hasil observasi akan dimasukkan ke dalam tabel rekapitulasi sebagai berikut:

Tabel 2.

Rekapitulasi Hasil Observasi Tentang Kegiatan Belajar Mengajar Oleh Guru Pendidikan Kewarganegaraan Di Madrasah Ibtidaiyah Negeri Kecamatan Tembilahan (Variabel Y)

\begin{tabular}{|c|c|c|c|c|c|c|c|}
\hline \multirow{2}{*}{ No } & \multirow{2}{*}{ TABEL } & \multicolumn{4}{|c|}{ HASIL OBSERVASI } & \multicolumn{2}{|c|}{ Jumlah } \\
\hline & & $\mathbf{Y a}$ & $\mathbf{P}(\%)$ & Tidak & $\mathbf{P}(\%)$ & $\mathbf{F}$ & $\mathbf{P}(\%)$ \\
\hline 1 & IV.10 & 9 & $100 \%$ & 0 & - & 9 & $100 \%$ \\
\hline 2 & IV.11 & 6 & $66,6 \%$ & 3 & $33,4 \%$ & 9 & $100 \%$ \\
\hline 3 & IV.12 & 5 & $55,5 \%$ & 4 & $44,5 \%$ & 9 & $100 \%$ \\
\hline 4 & IV.13 & 9 & $100 \%$ & 0 & - & 9 & $100 \%$ \\
\hline 5 & IV.14 & 6 & $66,6 \%$ & 3 & $33,4 \%$ & 9 & $100 \%$ \\
\hline 6 & IV.15 & 8 & $88,8 \%$ & 1 & $11,2 \%$ & 9 & $100 \%$ \\
\hline & MLAH & 43 & $79,6 \%$ & 11 & $20,4 \%$ & 54 & $100 \%$ \\
\hline
\end{tabular}

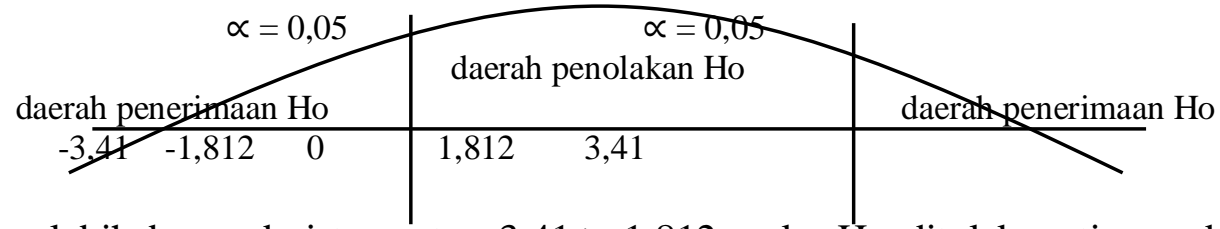

karena $t_{\text {hitung }}$ lebih besar dari $t_{\text {tabel }}$ atau 3,41 > 1,812 maka Ho ditolak, artinya ada hubungan yang signifikan antara pelaksanaan pengelolaan kelas terhadap kegiatan belajar mengajar pada mata pelajaran Pendidikan Kewarganegaraan di Madrasah Ibtidaiyah Negeri Kecamatan Tembilahan

Pengelolaan kelas yaitu suatu keterampilan guru untuk menciptakan dan memelihara kondisi belajar yang optimal bagi terjadinya proses belajar mengajar. ${ }^{8}$ Pengelolaan kelas adalah suatu upaya memberdayagunakan potensi kelas yang optimal mungkin untuk mendukung proses interaksi edukatif mencapai tujuan pembelajaran. ${ }^{9}$

${ }^{8}$ Syaiful Bahri Djamarah dan Aswan Zain. Strategi Belajar Mengajar (Jakarta: PT. Reneka Cipta, 2006), hlm. 194

${ }^{9}$ Syaiful Bahri Djamarah. Guru dan anak didik dalam interaksi edukatif suatu pendekatan teoritis psikologis, (Jakarta: PT Rineka Cipta, 2005), hlm. 173. 
Pengelolaan kelas adalah keterampilan guru untuk menciptakan dan memelihara kondisi belajar yang optimal dan keterampilan untuk mengembalikan kondisi belajar yang optimal apabila terdapat gangguan dalam proses belajar baik yang bersifat gangguan kecil dan sementara maupun yang bersifat gangguan yang berkelanjutan. ${ }^{10}$

Pengelolaan kelas juga merupakan seperangkat kegiatan untuk mengembangkan tingkahlaku siswa yang diinginkan, mengulang atau meniadakan tingkahlaku yang tidak diinginkan dengan hubungan-hubungan interpersonal dan iklim sosio emosional yang positif serta mengembangkan dan mempermudah organisasi kelas yang efektif. ${ }^{11}$

Pengelolaan kelas berarti pengaturan terhadap sebuah ruangan yang digunakan sebagai tempat dilaksanakannya suatu proses pembelajaran dengan tujuan agar pelaksanaan pembelajaran dapat berjalan dengan baik dan lancar. Tujuan pengelolaan kelas juga terdapat dalam tujuan pendidikan. Secara umum tujuan pengelolaan kelas adalah agar setiap anak di kelas dapat bekerja dengan tertib sehingga segera tercapai tujuan pengajaran secara efektif dan efesien. ${ }^{12}$

Pengelolaan kelas yang efektif, guru harus mempunyai tugas yang baik, adapun tugas guru tersebut dalam pengelolaan kelas adalah:

a. Memberikan rangsangan kepada siswa dengan menyediakan tugas-tugas pembelajaran dengan kaya, dan terancang baik untuk meningkatkan perkembangan intelektual, emosional, spritual, dan sosial siswa.

b. Berinteraksi dengan siswa untuk mendorong keberanian, mengilhami, menantang, berdiskusi, nerbagi, menjelaskan, menegaskan, merefleksi, menilai, dan merayakan perkembangan, pertumbuhan dan keberhasilan. Menunjukkan keuntungan atau manfaat yang diperoleh dari mempelajari suatu pokok bahasan.

c. Berperan sebagai seseorang yang membantu, seseorang yang mengarahkan dan memberikan penegasa, seseorang yang memberi jiwa dan mengilhami siswa dengan cara membangkitkan rasa ingin tahu, rasa antusias, dari seorang pembelajar yang berani mengambil resiko dengan demikian guru berperan sebagai pemberi informasi dan fasilatator.

d. Menciptakan suasana pembelajaran yang membuat siswa nyaman tinggal dikelas, menyenangkan, kondusif bagi terciptanya kreativitas dan inovasi juga demokratisasi sehingga efektif dalam mencapai tujuan.

e. Seorang guru harus memfasilitasi, mendukung, dan mengakomodasikan agar siswa mampu membangun pengetahuan sendiri, mengembangkan dan meningkatkan keterampilan, menggunakan terampilan agar dapat bekerja secara efektif, penuh percaya diri dan penuh kejujuran dan berperan sebagai individu yang mampu memilih dan menggunkan secara bijaksana. ${ }^{13}$

162.

${ }^{10}$ Didi Supriadie. Komunikasi pembelajaran, (Bandung: PT remaja rosdakarya, 2005), hlm.

${ }^{11}$ Hamid Darmadi. Kemampuan Mengajar Landasan Konsep dan Impelementasi, (Bandung: AlFebeta, 2009), hlm. 6.

${ }^{12}$ Syaiful Bahri Djamarah dan Aswan Zain. Op. cit., hlm. 200.

${ }^{13}$ Suyono, dkk. Belajar dan Pembelajaran Teori Dan Konsep Dasar, (Bandung: PT Remaja Rosdakarya, 2011), hlm. 237. 
Upaya memperkecil masalah gangguan dalam kelas, prinsip-prinsip pengelolaan kelas dapat dipergunakan. Maka adalah penting bagi guru untuk mengetahui dan menguasai prinsi-prinsip pengelolaan kelas, yang di uraikan berikut ini:

a. Hangat dan Antusias

Hangat dan antusias diperlukan dalam proses belajar mengajar. Guru yang hangat dan akrab dengan anak didik selalu menunjukkan antusias pada tugasnya atau pada aktivitasnya, akan berhasil dalam mengimplementasikan pengelolaan kelas.

b. Tantangan

Penggunaan kata-kata, tindakan, cara kerja atau bahan-bahan yang menantang akan meningkatkan gairah anak didik untuk belajar sehingga mengurangi kemungkinan munculnya tingkah laku yang menyimpang.

c. Bervariasi

Penggunaan alat atau media atau alat bantu, gaya mengajar guru, pola interaksi antara guru dan anak didik mengurangi munculnya gangguan, kevariasian dalam penggunaan apa yang di sebut di atas merupakan kunci untuk tercapainya pengelolaan kelas yang efektif.

d. Keluwesan

Keluwesan tingkah laku guru untuk mengubah strategi mengajarnya dapat mencegah kemungkinan munculnya gangguan anak didik serta menciptakan iklim belajar mengajar yang efektif.

e. Penekanan pada hal-hal yang positif

Pada dasarnya, dalam mengajar dan mendidik, guru harus menekankan pada hal-hal yang positif, dan menghindari pemusatan perhatian anak didik pada hal-hal yang negatif. Penekanan tersebut dapat dilakukan dengan pemberian penguatan yang positif, dan kesadaran guru untuk menghindari kesalahan Yang dapat mengganggu jalannya proses belajar mengajar.

f. Penanaman disiplin diri

Tujuan akhir dari pengelolaan kelas adalah anak didik dapat mengembangkan disiplin diri sendiri. Karena itu, guru sebaiknya selalu mendorong anak didik untuk melaksanakan disiplin diri sendiri dan guru sendiri hendaknya menjadi teladan mengenai pengendalian diri dan pelaksanaan tanggung jawab. Jadi, guru harus disiplin dalam segala hal bila ingin anak didiknya disiplin dalam segala hal. ${ }^{14}$

Upaya menciptakan suasana yang kondusif dalam proses pembelajaran, guru benar-benar perlu mengelola kelas dengan baik. Penyusunan dan pengaturan belajar 
hendaknya memungkinkan anak didik duduk berkelompok dan memudahkan anak didik bergerak secara leluasa.

Pengaturan ruang belajar, hal-hal yang diperhatikan adalah :

a. Ukuran dan bentuk kelas

b. Bentuk serta ukuran bangku dan meja anak didik

c. Jumlah anak didik dalam kelas

d. Jumlah anak didik dalam setiap kelompok

e. Jumlah kelompok dalam kelas

f. Komposisi siswa dalam kelompok. ${ }^{15}$

Pengelolaan kelas diperlukan karena hari kehari bahkan waktu kewaktu tingkah laku dan perbuatan anak didik selalu berubah. Oleh karena itu kelas harus dinamis dalam bentuk perilaku, perbuatan, sikap mental, dan emosional anak didik. Jadi pengelolaan kelas adalah suatu upaya memberdayakan potensi kelas yang seoptimal mungkin untuk mendukung proses interaksi edukatif menciptakan tujuan pembelajaran. ${ }^{16}$

Oleh sebab itu dalam pengelolaan kelas ada beberapa langkah yang harus dilakukan oleh guru diantaranya adalah:

a. Pengaturan tempat duduk

Tempat duduk cukup mempengaruhi siswa dalam belajar, tempat duduk yang tidak ideal dapat membuat siswa tidak nyaman dan mempengaruhi konsentrasi siswa.

Bentuk posisi ini sebaiknya disesuaikan dengan metode pengajaran yang digunakan, seperti posisi melingkar untuk penggunaa metode diskusi, posisi berbaris kebelakang untuk menggunakan metode ceramah, dan lainnya.

b. Pengaturan alat pengajaran

Cara pengaturan peralatan dapat diatur sebagai berikut:

1. Perpustaan Kelas

- Sekolah yang maju ada di setiap kelas

- Pengaturannya bersama-sama siswa

2. Alat-alat Peraga Media Pengajaran

- Alat peraga atau media pengajaran semestinya diletakkan dikelas agar memudahkan dalam penggunaannya

- Pengaturannya bersama-sama siswa.

3. Papan Tulis, Kapur Tulis, dan lain-lain

- Ukurannya disesuiakan

- Warnanya harus kontras

- Penempatannya memperlihatkan estetika dan terjangkau oleh semua siswa

${ }^{15}$ M. Syafi'i. S. Strategi Belajar Mengajar. (Pekanbaru: 1996), hlm. 65.

${ }^{16}$ Syaiful Bahri Djamarah. Guru Dan Anak Didik Dalam Interaksi Edukatif Suatu Pendekatan Teoritis Psikologis, (Jakarta: PT Rineka Cipta, 2005), hlm. 172. 
4. Papan Presensi Siswa

- Ditempatkan di bagian depan sehingga dapat dilihat oleh semua siswa

- Difungsikan sebagaimana mestinya

c. Penataan keindahan dan kebersihan kelas

1. Hiasan dinding (pajangan kelas) hendaknya dimanfaatkan untuk kepentingan pengajaran, misalnya:

- $\quad$ burung Garuda

- para pahlawan

- peta/globe

2. Penempatan lemari

- Untuk buku di depan

- $\quad$ Alat-alat peraga di belakang

3. Pemeliharaan kebersihan

- Siswa bergiliran untuk membersihkan kelas (piket)

- Guru memeriksa kebersihan dan ketertiban di kelas.

d. Ventilasi dan pencahayaan

- Ada ventilasi yang sesuai dengan ruangan kelas.

- Tidak merokok di ruangan.

- Pengaturan cahaya perlu diperhatikan.

- Cahaya yang masuk harus cukup. ${ }^{17}$

Pelaksanaan pengelolaan kelas ada beberapa terhadap kegiatan belajar mengajar ada beberapa faktor yang mempengaruhi, diantaranya:

a. Guru

Guru adalah salah satu komponen manusiawi dalam proses belajar mengajar, yang ikut berperan dalam usaha pembentukan sumber daya manusia yang potensial dibidang pembangunan. Oleh sebab itu guru yang merupakan salah satu unsur di bidang kependidikan harus berperan secara aktif dan menempatkan kedudukannya sebagai tenaga profesional. ${ }^{18}$

b. Siswa

Siswa/anak didik adalah manusia berpotensi yang menghajatkan pendidikan. Di sekolah. Gurulah yang berkewajiban mendidiknya. ${ }^{19}$

c. Fasilitas

Fasilitas merupakan hal yang mempengaruhi pemilihan dan penentuan metode mengajar. Fasilitas juga merupakan kelengkapan yang menunjang belajar anak didik di sekolah. ${ }^{20}$

${ }^{17}$ Ibid., hlm. 175.

${ }^{18}$ Sardiman. Intraksi dan Motivasi Belajar Mengajar, (Jakarta: PT Raja Grafindo Persada, 2003), hlm. 125.

${ }^{19}$ Syaiful Bahri Djamarah. Op.cit., hlm. 89.

${ }^{20} \mathrm{Ibid}$., hlm. 92. 
d. Kurikulum

Kurikulum diartikan sebagai sejumlah kegiatan yang diberikan kepada siswa, kegiatan itu sebagian besar adalah menyajikan bahan pelajaran agar siswa menerima, menguasai dan mengembangakan bahan pelajaran itu. ${ }^{21}$

\section{KESIMPULAN DAN SARAN}

Berdasarkan hasil observasi dan wawancara yang penulis lakukan terhadap guru Pendidikan Kewarganegaraan di Madrasah Ibtidaiyah Negeri Kecamatan Tembilahan maka dapat disimpulkan bahwa:

1. Hubungan pelaksanaan pengelolaan kelas terhadap kegiatan belajar mengajar pada mata pelajaran Pendidikan Kewarganegaraan di Madrasah Ibtidaiyah Negeri Kecamatan Tembilahan tidak ada hubungannya ini terlihat dari hasil akhir yang penulis temukan bahwa $t_{\text {hitung }}$ lebih besar dari $t_{\text {tabel }}$ atau 3,41> 1,812 maka Ho ditolak, artinya ada hubungan yang signifikan.

2. Adapun faktor yang mempengaruhi pelaksanaan pengelolaan kelas terhadap kegiatan belajar mengajar pada mata pelajaran Pendidikan Kewarganegaraan di Madrasah Ibtidaiyah Negeri Kecamatan Tembilahan yaitu faktor guru, siswa, fasilitas dan kurikulum.

\section{DAFTAR PUSTAKA}

Didi Supriadie, dkk. (2009). Komunikasi Pembelajaran. Bandung: PT Remaja Rosdakarya.

E. Mulyasa. (2007). Kurikulum Tingkat Satuan Pendidikan. Bandung: Remaja Rosdakarya.

Hamid Darmadi. (2009). Kemampuan Mengajar Landasan Konsep dan Impelementasi. Bandung: AlFebeta.

Haris Herdiansyah. (2010). Metodologi Penelitian Kualitatif Untuk Ilmu-Ilmu Sosial. Jakarta: Selemba Humanika.

Hasan Alwi. (2002). Kamus Besar Bahasa Indonesia edisi ketiga. Jakarta: Balai Pustaka.

Isjoni. (2003). Evaluasi Belajar Mengajar. Pekanbaru: UNRI Press.

Isjoni. (2005). Citra Guru Antara Tuntutan dan Pengabdian. Pekanbaru: UNRI Press.

\footnotetext{
${ }^{21}$ Slameto. Op.cit., hlm. 65
} 
ISSN: 2443-0021 e-ISSN: 2716-4136

Nia Pratiwi, Mardiah (2020)

Kasful Anwar Us. (2011). Perencanaan Sistem Pembelajaran Kurikulum Tingkat Satuan Pendidikan (KTSP). Bandung: Alfabeta.

Lexy .J. Moleong. (2000). Meteodologi Penelitian Kualitatif. Bandung: Remaja Rosdakarya.

Moh. Uzer Usman. (2005).Menjadi Guru Profesional. (Bandung: PT. Remaja Rosda Karya.

Muhammad Ali. (2008). Guru Dalam Proses Belajar Mengajar. Bandung: Sinar Baru Algensindo.

M. Syafi'i. S. (1996). Strategi Belajar Mengajar. Pekanbaru.

Ngalim Purwanto. (2008). Prinsip-Prinsip Evaluasi Pengajaran. Jakarta: PT Remaja Rosdakarya.

Riduwan. (2004). Belajar Mudah Penelitian untuk Guru, Karyawan dan Penelitian Pemula. Bandung: Alfabeta.

Sardiman. (2003). Intraksi dan Motivasi Belajar Mengajar. Jakarta: PT Raja Grafindo Persada.

Sugiono. (2010). Metode Penelitian Pendidikan. Bandung: AlFabeta.

Suharsimi Arikunto. (2002). Prosedur Penelitian Suatu Pendekatan Praktek, Edisi Revisi V. Jakarta: Rineka Cipta.

Sukardi. (2003). Metodologi Penelitian Pendidikan Kompetensi dan Praktiknya. Jakarta: Bumi Aksara.

Sulchan Yasyin. (1995). Kamus Pintar Bahasa Indonesia. Surabaya: Amanah.

Suyono, dkk. (2011). Belajar dan Pembelajaran Teori Dan Konsep Dasar. Bandung: PT Remaja Rosdakarya.

Syaiful Bahri Djamarah dan Aswan Zain. (2006). Strategi Belajar Mengajar. Jakarta: PT. Reneka Cipta.

Syaiful Bahri Djamarah. (2005). Guru dan anak didik dalam interaksi edukatif suatu pendekatan teoritis psikologis. Jakarta: PT Rineka Cipta. 